\title{
Commentary
}

\section{Role of DNA Damage and Repair in Detrimental Effects of Ionizing Radiation}

\author{
Alexandros G. Georgakilas $\mathbb{D}$ \\ DNA Damage Laboratory, Physics Department, School of Mathematical and Physical Sciences, National \\ Technical University of Athens, Hroon Polytexneiou 9, 15780 Zografou, Greece; alexg@mail.ntua.gr; \\ Tel.: +30-210-7724453
}

Received: 18 September 2020; Accepted: 10 October 2020; Published: 22 October 2020

\begin{abstract}
Ionizing radiation (IR) is considered a traditional mutagen and genotoxic agent. Exposure to IR affects in all cases biological systems and living organisms from plants to humans mostly in a pernicious way. At low ( $<0.1 \mathrm{~Gy})$ and low-to-medium doses $(0.1-1 \mathrm{~Gy})$, one can find in the literature a variety of findings indicating sometimes a positive-like anti-inflammatory effect or detrimental-like toxicity. In this Special Issue and in general in the current research, we would like to acquire works and more knowledge on the role(s) of DNA damage and its repair induced by ionizing radiations as instigators of the full range of biological responses to radiation. Emphasis should be given to advances offering mechanistic insights into the ability of radiations with different qualities to severely impact cells or tissues. High-quality research or review studies on different species projected to humans are welcome. Technical advances reporting on the methodologies to accurately measure DNA or other types of biological damage must be highly considered for the near future in our research community, as well. Last but not least, clinical trials or protocols with improvements to radiation therapy and radiation protection are also included in our vision for the advancement of research regarding biological effects of IR.
\end{abstract}

Keywords: radiation effects; clustered DNA damage; DNA repair; radiation therapy; radiation protection; systemic effects of radiation

\section{Introduction}

Current research needs in the field of biological effects of IR signify also the trends in the literature. Undoubtedly on the major questions that dominate the field, it is how IR impacts the life of an organism and especially humans? We all accept that the exposure of a living organism to radiation has usually detrimental effects and in some cases a positive impact of unsure nature. Over the years, accumulated knowledge of the physical and chemical mechanisms of IR interaction with biological matter and predominantly water $\left(\mathrm{H}_{2} \mathrm{O}\right)$ has substantiated the deeper understanding of the ways that IR damages cells (DNA, proteins, and lipids) and the repair (amendment) pathways utilized by the cell. This knowledge has been extended to the enhanced comprehension of the final biological outcome such as persistent DNA damage, mutations, genomic instability, cell death or senescence and systemic (non-targeted) effects of radiation (an upcoming field) [1].

A significant improvement of detection methodologies has pushed forward the field opening opportunities to detect in situ biological damage using, for example, fluorescence, electron, or atomic force microscopy [2-5]. These techniques' advancements have helped delineate to a greater extent the mechanisms involved in the processing of IR-induced biological damage to DNA, proteins, or lipids. More importantly, to shed light towards the DNA damage response (DDR) mechanisms and how the cell confronts complex (clustered) or highly complex (very dense) DNA damage induced, for example, 
by high-LET (LET: Linear energy transfer $=-d E / d x$, differential in which $-d E$ is the energy loss and $d x$ denotes the increment of path length) radiations such as heavy ions, $\alpha$-particles, etc. $[6,7]$.

\section{Current Needs in Research of Radiation Effects on Biological Systems}

If one looks back on the history of IR-induced biological effects even from the 80s, emphasis was given on the differences between low- $(X, \gamma$ rays) and high-LET radiations such as $\alpha$-particles towards, for example, the induction of cell killing. Survival curves for X-rays and $\alpha$-particles were so different in bringing up the repair resistant nature of particle-induced DNA damage [8]. Since the 80s and through the aid of Monte Carlo simulations and especially of tract-structure codes (for a recent review, please see [9]), a clearer view of the role(s) of complex damage induced by IR has been obtained. Over the years through mainly the improvement of experimental methodologies, this view has been furthered to the current agreement of its pivotal role in determining a variety of biological effects in any living organism. The effects of low doses $(<0.1$ Gy) of IR still remain an open field with many uncertainties extended to a medium dose such as $0.5 \mathrm{~Gy}$ of X-rays reported to have, for example, an immune-modulatory (anti-inflammatory) effect even in the case of COVID-19 related pneumonopathy [10,11].

Current questions and needs in radiation research can be summarized in the following suggested points:

1. What are the levels and types of DNA damage induced in the nucleus or other nucleic acid containing cellular compartments such as, for example, mitochondria?

2. Considering DNA, proteins, and lipids (DPL) as isolated cellular components, we need to advance towards a deeper understanding of all the mechanistic chemical links between radiation and free radicals interacting with DPL.

3. Considering the interaction of DPL, we need to answer better how this interaction, for example, between DNA and proteins impacts their interaction with radiation or IR-oxidative attack, and

4. How this damage to DPL can be communicated to bystander or distant cells and to the whole organism (systemic effects)?

5. Can we improve Monte Carlo (MC) or mathematical and computing simulations and codes to better predict the damage and repair of IR-DNA lesions?

\section{Conclusions and Future Directions}

Taking into consideration all the above, we believe in the need of multidisciplinary approaches in order to secure the advancement in the radiation effects field for the next decade or so. Not only better and more accurate in situ techniques and methodologies are needed as described above, but also the use of systems biology and the fingerprinting of the crosstalk between DDR and immune system (Figure 1). The mechanistic links between induction of damage by IR at a specific site (tumor) and the propagation of stress signals in distant sites is of upcoming major importance $[12,13]$. The use of bioinformatics and omics technologies is definitely an advantageous aspect of technological improvements [14].

The persistence of DNA or other types of biological damage often can lead to the release of danger signals often called DAMPs (damage-associated molecular patterns) that can create a negative and unfortunately sustainable excessive inflammatory and immune response dictating a variety of toxic effects of IR, such as in the case of radiation therapy [15]. In addition, one needs to better comprehend the role of complex DNA damage in directing the cell towards cell death or senescence. Currently, we do not have a clear picture which level or type of damage will lead to cell death or senescence in a specific biological system [16,17]. 


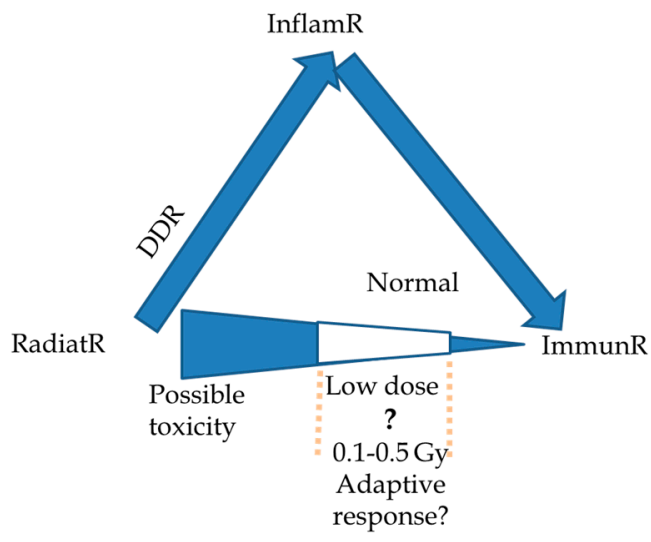

Figure 1. Interactions between ionizing radiation (IR) and living organisms manifested as an interactive dynamic balance triangle of response to radiation (RadiatR)-inflammatory response (InflamR) and immune response (ImmunR). The persistence of InflamR will lead according to a current understanding of radiation toxicity. Uncertainties still prevail in the low-to-medium dose region where IR might have also positive or adaptive response effects.

Funding: This research received no external funding.

Acknowledgments: A.G.G. acknowledges the helpful discussions with colleagues and members of his research group in NTUA (Postdocs and PhD students).

Conflicts of Interest: The author declares no conflict of interest.

\section{References}

1. Mavragani, I.V.; Nikitaki, Z.; Kalospyros, S.A.; Georgakilas, A.G. Ionizing Radiation and Complex DNA Damage: From Prediction to Detection Challenges and Biological Significance. Cancers 2019, 11, 1789. [CrossRef] [PubMed]

2. Aleksandrov, R.; Dotchev, A.; Poser, I.; Krastev, D.; Georgiev, G.; Panova, G.; Babukov, Y.; Danovski, G.; Dyankova, T.; Hubatsch, L.; et al. Protein Dynamics in Complex DNA Lesions. Mol. Cell 2018, 69, 1046-1061.e5. [CrossRef] [PubMed]

3. Jakob, B.; Dubiak-Szepietowska, M.; Janiel, E.; Schmidt, A.; Durante, M.; Taucher-Scholz, G. Differential Repair Protein Recruitment at Sites of Clustered and Isolated DNA Double-Strand Breaks Produced by High-Energy Heavy Ions. Sci. Rep. 2020, 10, 1443. [CrossRef] [PubMed]

4. Scherthan, H.; Lee, J.-H.; Maus, E.; Schumann, S.; Muhtadi, R.; Chojowski, R.; Port, M.; Lassmann, M.; Bestvater, F.; Hausmann, M. Nanostructure of Clustered DNA Damage in Leukocytes after In-Solution Irradiation with the Alpha Emitter Ra-223. Cancers 2019, 11, 1877. [CrossRef] [PubMed]

5. Xu, X.; Nakano, T.; Tsuda, M.; Kanamoto, R.; Hirayama, R.; Uzawa, A.; Ide, H. Direct observation of damage clustering in irradiated DNA with atomic force microscopy. Nucleic Acids Res. 2019, 48, e18. [CrossRef] [PubMed]

6. Nickoloff, J.A.; Sharma, N.; Taylor, L. Clustered DNA double-strand breaks: Biological effects and relevance to cancer radiotherapy. Genes 2020, 11, 99. [CrossRef] [PubMed]

7. Hill, M.A. Radiation Track Structure: How the Spatial Distribution of Energy Deposition Drives Biological Response. Clin. Oncol. 2019. [CrossRef] [PubMed]

8. Prise, K.M.; Davies, S.; Michael, B.D. The relationship between radiation induced double-strand breaks and cell killing in hamster V79 fibroblasts irradiated with $250 \mathrm{kVp}$ X-rays, $2.3 \mathrm{MeV}$ neutrons, or 238Pu alpha particles. Int. J. Radiat. Biol. 1987, 115, 893-902.

9. Chatzipapas, K.P.; Papadimitroulas, P.; Emfietzoglou, D.; Kalospyros, S.A.; Hada, M.; Georgakilas, A.G.; Kagadis, G.C. Ionizing Radiation and Complex DNA Damage: Quantifying the Radiobiological Damage Using Monte Carlo Simulations. Cancers 2020, 12, 799. [CrossRef] [PubMed] 
10. Rodel, F.; Arenas, M.; Ott, O.J.; Fournier, C.; Georgakilas, A.G.; Tapio, S.; Trott, K.R.; Gaipl, U.S. Low-dose radiation therapy for COVID-19 pneumopathy: What is the evidence? Strahlenther. Onkol. 2020, 196, 679-682. [CrossRef] [PubMed]

11. Rodel, F.; Frey, B.; Manda, K.; Hildebrandt, G.; Hehlgans, S.; Keilholz, L.; Seegenschmiedt, M.H.; Gaipl, U.S.; Rodel, C. Immunomodulatory properties and molecular effects in inflammatory diseases of low-dose x-irradiation. Front. Oncol. 2012, 2, 120. [CrossRef] [PubMed]

12. Rodriguez-Ruiz, M.E.; Vanpouille-Box, C.; Melero, I.; Formenti, S.C.; Demaria, S. Immunological Mechanisms Responsible for Radiation-Induced Abscopal Effect. Trends Immunol. 2018, 39, 644-655. [CrossRef] [PubMed]

13. Lobachevsky, P.N.; Ventura, J.; Giannakandropoulou, L.; Forrester, H.; Palazzolo, J.S.; Haynes, N.M.; Stevenson, A.W.; Hall, C.J.; Mason, J.; Pollakis, G.; et al. A Functional Immune System Is Required for The Systemic Genotoxic Effects of Localised Irradiation. Int. J. Radiat. Oncol. Biol. Phys. 2019, 103, 1184-1193. [CrossRef] [PubMed]

14. Georgakilas, A.G.; Pavlopoulou, A.; Louka, M.; Nikitaki, Z.; Vorgias, C.E.; Bagos, P.G.; Michalopoulos, I. Emerging molecular networks common in ionizing radiation, immune and inflammatory responses by employing bioinformatics approaches. Cancer Lett. 2015, 368, 164-172. [CrossRef] [PubMed]

15. Ruckert, M.; Deloch, L.; Fietkau, R.; Frey, B.; Hecht, M.; Gaipl, U.S. Immune modulatory effects of radiotherapy as basis for well-reasoned radioimmunotherapies. Strahlenther. Onkol. 2018, 194, 509-519. [CrossRef] [PubMed]

16. Gorgoulis, V.; Adams, P.D.; Alimonti, A.; Bennett, D.C.; Bischof, O.; Bishop, C.; Campisi, J.; Collado, M.; Evangelou, K.; Ferbeyre, G.; et al. Cellular Senescence: Defining a Path Forward. Cell 2019, 179, 813-827. [CrossRef] [PubMed]

17. Feringa, F.M.; Raaijmakers, J.A.; Hadders, M.A.; Vaarting, C.; Macurek, L.; Heitink, L.; Krenning, L.; Medema, R.H. Persistent repair intermediates induce senescence. Nat. Commun. 2018, 9, 3923. [CrossRef] [PubMed]

Publisher's Note: MDPI stays neutral with regard to jurisdictional claims in published maps and institutional affiliations.

(C) 2020 by the author. Licensee MDPI, Basel, Switzerland. This article is an open access article distributed under the terms and conditions of the Creative Commons Attribution (CC BY) license (http://creativecommons.org/licenses/by/4.0/). 